\title{
Tardigrades (Tardigrada) in Baltic States
}

\section{Ingrida ŠATKAUSKIENÉ}

Department of Biology,

Vytautas Magnus University,

Vileikos 8, LT-44404 Kaunas,

Lithuania
The tardigrades (Tardigrada), one of the micrometazoans groups, are reviewed. Tardigrades are distributed almost everywhere: in moss, lichens, soil, in niches of freshwater and seawater. The ability of tardigrades to undergo cryptobiosis has aroused interest among world scientists who would like to apply this mechanism to other biological systems that might benefit from dry storage in extreme conditions. This paper reviews the latest information on tardigrades taxonomy and phylogenetic position, distribution, some aspects of their biology, reproduction and life history. The present work also provides the data of research of tardigrades in the Baltic states.

Key words: tardigrada, eutardigrada, heterotardigrada, freshwater, life history, anhydrobiosis, cryptobiosis

\section{INTRODUCTION}

Scientific knowledge of invertebrates varies from group to group. The best-studied groups are insects, crustaceans and mollusks. Even in these well-studied groups, there are huge information gaps, especially for smaller animals and those living in developing countries or underground habitats (Strayer, 2006). Little is known about "minor" phyla: bryozoans (Ryland, 2005; Dunn et al., 2008; Massard, Geimer, 2008), gastrotrichs (Balsamo et al., 2008; Kieneke et al., 2012; Paps, Riutort, 2012), nematomorphs (Hanelt et al., 2005; Poinar, 2008) and freshwater tardigrades (McFatter et al., 2007; Garey et al., 2008; Meyer, 2011). Meanwhile some

\footnotetext{
* Corresponding author. E-mail: i.satkauskiene@gmf.vdu.lt
}

of these groups are widespread and abundant. For example, gastrotrichs probably occur in most freshwater habitats throughout the world (Strayer, 2006). The tardigrades are one of most abundant invertebrates in moss and lichens, meanwhile little is known about the tardigrades in the Baltic countries.

Some of these micrometazoans could be used as bioindicators, as model organisms for studies of development mechanisms or for experiments in the open space.

Tardigrades are referred to as one of the "lesserknown" groups of micrometazoans (Nelson, 2002; Romano, 2003). Presently, the exact number of various Tardigrada species is unknown. In order to increase knowledge about these invertebrates and also to explore the possible biotechnological 
and biomedical applications of their biology, more economic and human resources need to be focused on this group (Guil, Cabrero-Sañudo, 2007). The aim of this study was to summarize the latest information on tardigrades biology, significance and provide the most recent research data on tardigrades in the Baltic States.

\section{Some aspects of tardigrade biology}

Tardigrada is known as "water bear" that bears this descriptive name based on the animal's lumbering gait (tardi - slow, grade - walker) and also because these invertebrates usually live in water. Tardigrades are one of the smallest metazoa and their size is close to that of rotifera, gastrotricha or microscopic nematodes. Body length of adult tardigrade is approximately $250-500 \mu \mathrm{m}$ (Nelson, 2002). Like in the arthropods, the body of tardigrades is covered by cuticle. External layer of cuticle is soft, lacks calcium and is built from a protein albuminoid which differs from chitin (Gagyi-Palffy, Stoian, 2011). The inner layer of the cuticle contains chitin. Tardigrades molt and change their cuticle like the arthropods. Molting occurs every five to ten days throughout the tardigrade's life (Nelson, 2002).

Water bear may be detritovorious, bacteriovorous, carnivorous and herbivorous (Romano, 2003). Irrespective of the wide range of food consumption, tardigrades do not display a great variation in the organization of the digestive system. The tardigrade buccal-pharyngeal apparatus that is used to suck out the content of cells is a complex structure with a considerable taxonomic significance among taxa belonging to several taxonomic levels, particularly in the eutardigrades (Pilato, Binda, 2010). The buccal-pharyngeal apparatus consists of cuticular structures such as a buccal ring, a buccal tube with apophyses for muscle attachments, stylets and a muscular sucking pharynx (containing placoids) (Nelson et al., 2010; Guidetti et al., 2012) (Fig. 1).

During the last decade various aspects of anatomy and physiology of Tardigrada have been studied. Greven (2007) provided information on the visual organs of tardigrada. Many Eutardigrada and some of Echiniscidae possess inverse pigment-cup ocelli, which are located in the outer lobe of the brain, and probably are of cerebral origin (Fig. 2). Depending on the species, response to light (photokinesis) is negative, positive or indifferent and may change during the ontogeny. Greven (2007) states that the homology of the tardigrade eyes with the visual organs of other bilaterians is difficult to establish and further comparative studies are needed.

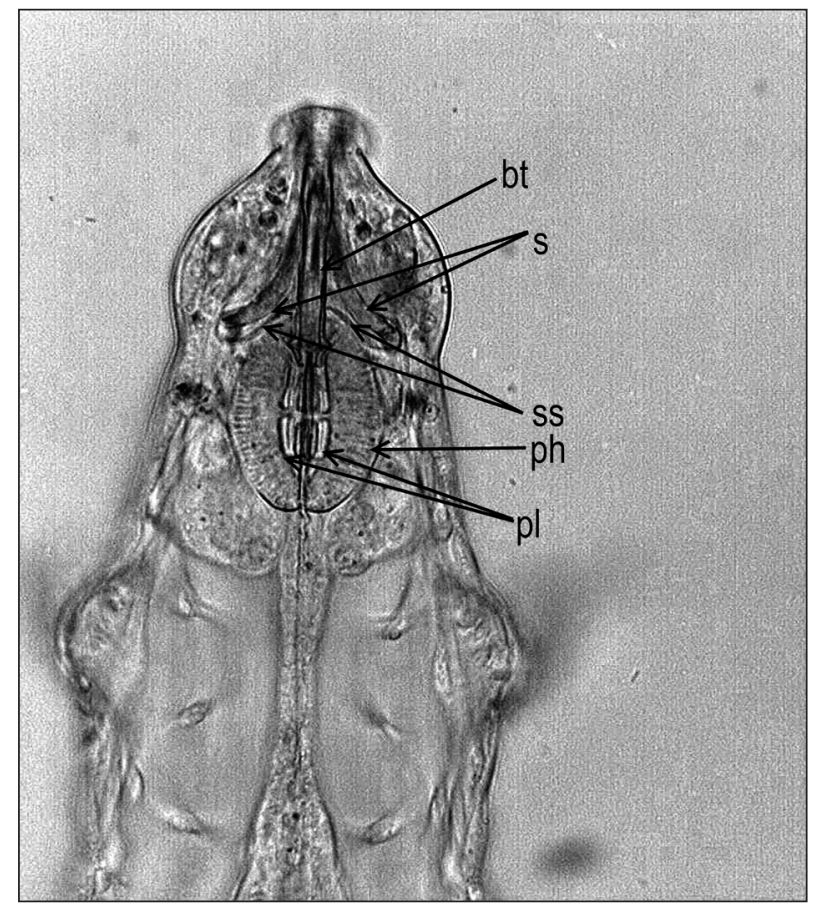

Fig. 1. General structure of buccal apparatus of eutardigrade. $m$, mouth; $b t$, buccal tube; $s$, stylets (which serve as a tool to pierce plant cells); ss, stylet supports; ph, pharynx; $p l$, placoids

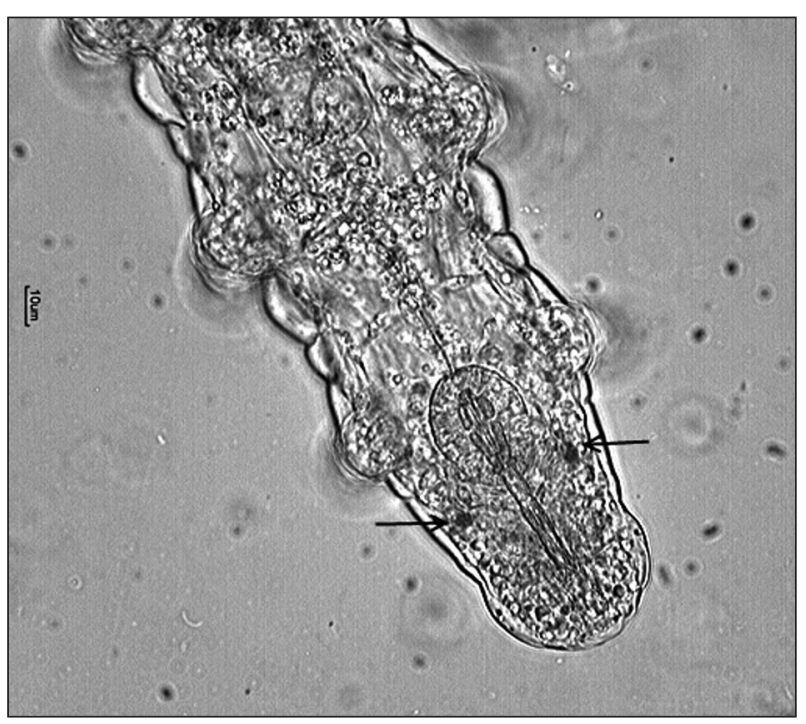

Fig. 2. The anterior part of the body of tardigrade with two eyes (arrows) 
The analysis of the nervous system of Tardigrada plays an important role considering the phylogenetic afinities of the groups (Dewel, Dewel, 1996, 1997; Nielsen, 2001). Although the central nervous system of tardigrades is generally described as belonging to the rope-ladder-like type comprised of ganglia with connectives and commissures, unambiguous documentation of commissures is almost absent in the literature (Zantke et al., 2008). Meanwhile the use of more neuroanatomical data of Tardigrada should contribute to our understanding of tardigrade phylogenetic afinities in a more global approach considering a variety of morphological and molecular data (Zantke et al., 2008).

Considering the reproduction system of tardigrades it is noteworthy that it is variable and species-dependent, it may be dicoeciuos, hermaphroditic and may reproduce in sexual or parthenogenetical way. Using cryptobiosis and passive dispersal, parthenogenesis is favorable in colonizing new, isolated and unstable habitats, as beginning with a single individual is all that is required (Altiero et al., 2006). For marine species (mainly heterotardigrades) parthenogenesis is unknown, meanwhile in limno-terrestrial tardigrades always appear continuous (Bertolani, 2001). Hermaphroditism in limno-terrestrial species occurs in several eutardigrade families (Pilato et al., 2006) and in Heterotardigrada only one species is hermaphroditic (Bertolani, 2001). Hermaphroditism is not common in tardigrades, indicating that this model of reproduction is a less frequent sexual condition. The findings of a hermaphroditic species confirm that in tardigrades this condition develops independently in different evolutionary lines (Pilato et al., 2006).

Sexual dimorphism was established for one species of Heterotardigrada - Echiniscus mauccii (Mitchell, Romano, 2007) and three other Echiniscus species (Miller et al., 1999). Females, distinguished by their gonopore, are larger than males (Mitchel, Romano, 2007). Similar sexual dimorphism (females are larger than males) is observed in two eutardigrada species: Macrobiotus richtersi and Hypsibius convergens (Guidetti et al., 2007). Data covering the gametogenesis of Tardigrada is especially scarce (Poprawa, 2005).

Reproduction of tardigrades is coupled with molt. The female subsequently moults, laying her eggs in the shed cuticle (Fig. 3). Gonad size is constrained by the cuticle capacity and by the gut size (food source) that competes for the space within the body cavity (Guidetti et al., 2007).

All tardigrada produce eggs, which consist of polysaccharides, peptides and lipids (Poprawa, 2005) and are often essential for a correct identification of tardigrada species (Fig. 4a, 4b, 4c) (Cromer et al., 2007).

The behavior and chemical communication at the time of reproduction of tardigrades are unknown. The information on the origin and rele-

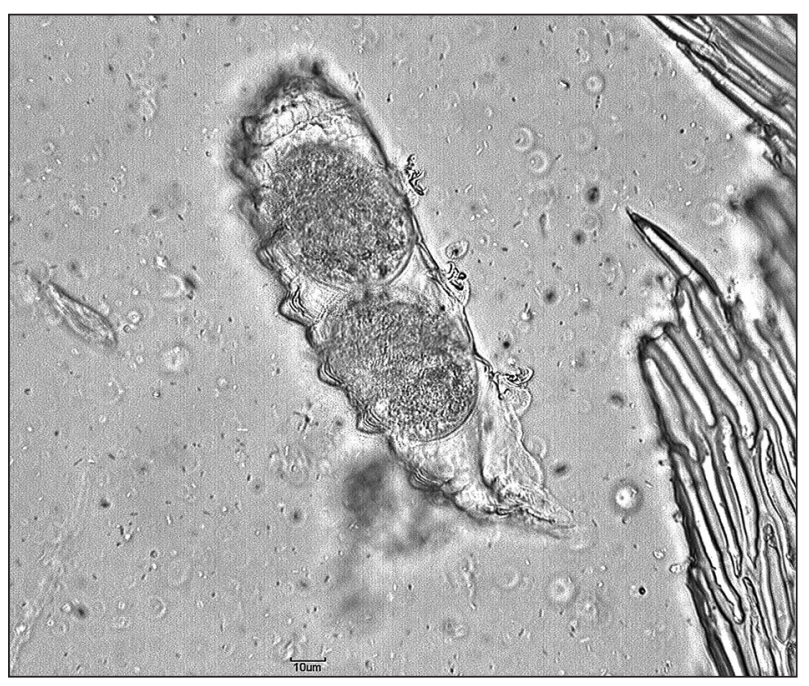

Fig. 3. Many tardigrades store their eggs underneath the cuticle, afterwards shed them along with the cuticle when moulting

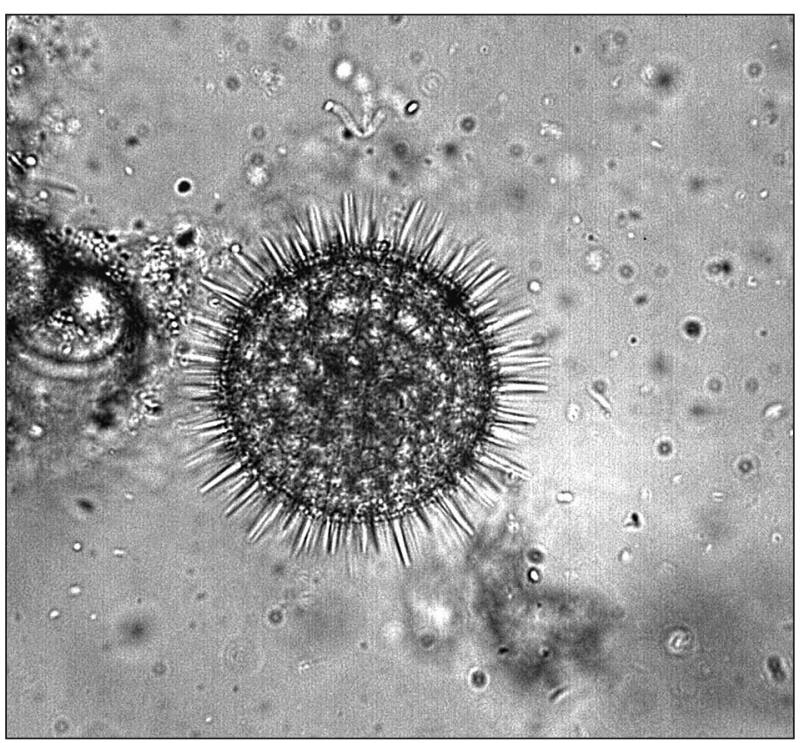

Fig. 4a. The egg of Richtersius coronifer found in moss Bryum sp. 


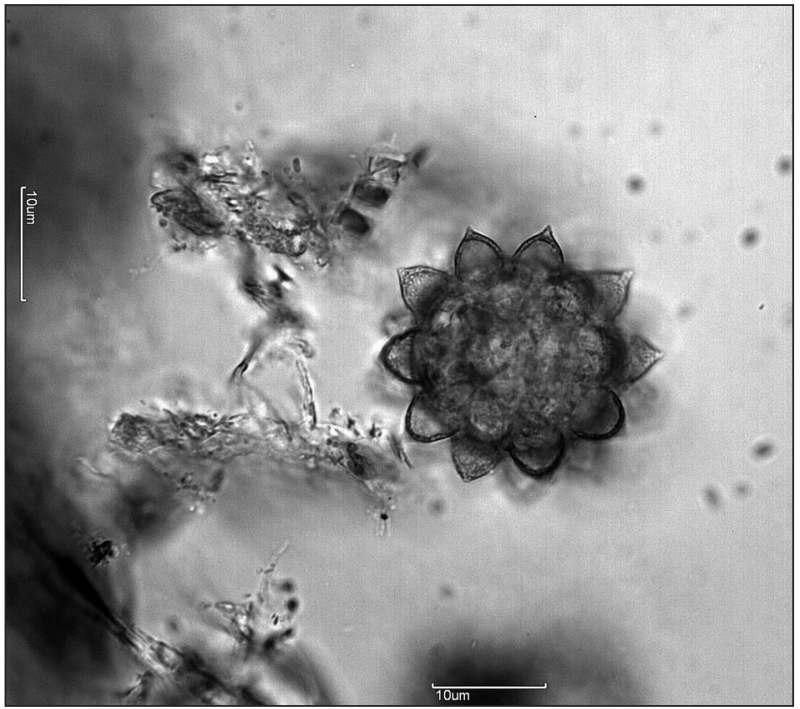

Fig. 4b. The egg of Macrobiotus richtersii (?) found in moss Pleurozium schreberi

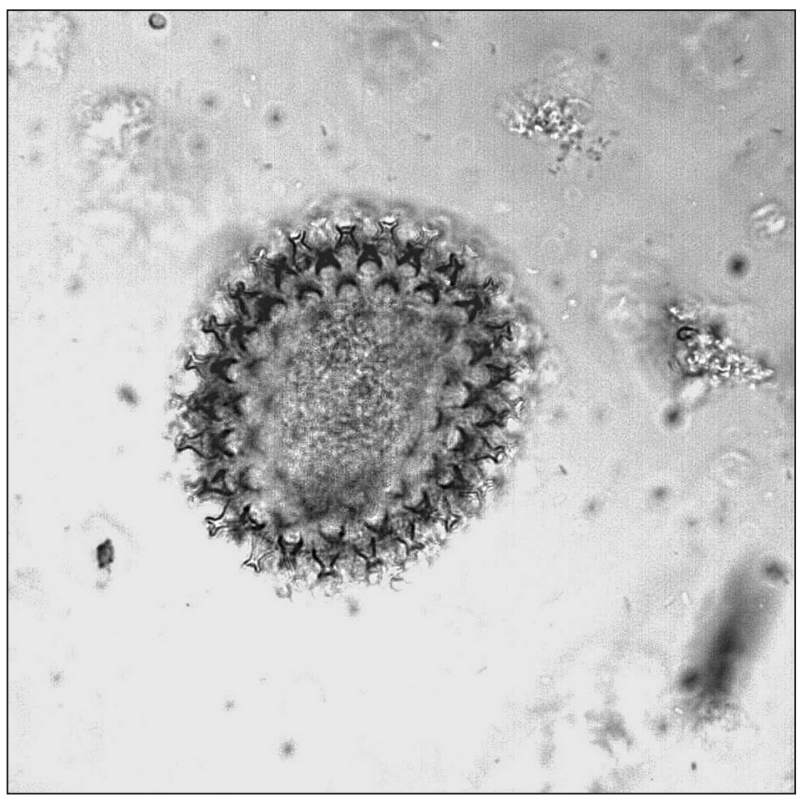

Fig. 4c. The egg of Macrobiotus hufelandi found in moss Bryum sp.

vance of sex steroid receptors in invertebrates are still limited (Köhler et al., 2007).

Parental care is not common in tardigrades, however Pilato et al. (2006) mentioned that newborns of Hypsibius zetlandicus (Eutardigrada) are still within the old cuticle of the parent and this could be an indication of the possibility of "parental care".

Time of reproduction is not clear for many species of tardigrades. Mitchel and Romano (2007) observed that sexual reproduction of
Echiniscus mauccii continues for the entire year and suggested that this species has classic K-selected traits.

Life history traits are always very interesting subjects in the study of animal adaptation and evolution. Despite this importance, literature data on the life history traits and population dynamics of freshwater and semiterrestrial species of tardigrades are scanty and fragmentary (Mitchell, Romano, 2007), while actually no data are available for marine species (Altiero et al., 2006).

\section{Distribution and habitats of tardigrades}

The phylum Tardigrada has a worldwide distribution (Nelson, 2002; Bertolani et al., 2004) that is related with the ability of Tardigrada to survive in extreme environments and to use cryptobiosis together with passive dispersal and parthenogenesis. Theoretically, parthenogenesis allows the colonization of new and remote territories beginning with a single individual (Miller, Heatwole, 1996; Bertolani, 2001). Despite this possibility to spread, a very high number of tardigrada species have limited geographical distribution and are adapted to restricted microenvironmental conditions (Pilato et al., 2006).

Tardigrades use various habitats: marine and estuarine, freshwater and terrestrial. Information on the distribution and ecology of limnoterrestrial Tardigrada is scarce (McFatter et al., 2007). They are benthic or crawl on water vegetation. Most species live in the littoral zone (Nelson, 2002). The majority of these organisms are not real hidrophylous and are found in terrestrial and aquatic environments. Numerically, limnoterrestrial tardigrades comprise a minor component of benthic invertebrate communities. Knowledge is lacking about their tropic relationships or dispersal in benthic habitats (McFatter et al., 2007).

Terrestrial tardigrades are inhabitants of mosses, lichens, soil and leaf litter. Tardigrades in leaf litter from beech forests (Guidetti et al., 1999) and soil (Bertolani et al., 1996; Nelson, 2002) exhibit high species diversity and high densities, but the evidence of tardigrades for substrate specificity is weak. Many species of tardigrades may be present in soil and leaf litter, but few were found only in these substrates (Meyer et al., 2007). Jönsson (2003) indicated that different mosses' growth 
form might have an impact on tardigrada abundance. Meyer $(2006$; 2007) noted that some tardigrada species were significantly associated with mosses or foliose lichens in general, but no significant association was detected between a tardigrada species and a substrate species.

Tardigrada densities in soil are high and may vary from 300 to 33,600 individuals in $\mathrm{m}^{2}$ (Hohberg, 2006). Soil-inhabiting tardigrades have high metabolic rates, hence they are sensitive to subtle environmental variances and respond to structural changes in the soil (Harada, Ito, 2006).

There are few studies on the relation of tardigrada diversity and richness and season. Some scientists have proposed that tardigrada communities are stable through time and there are not significant differences comparing the tardigrada density and community structure between different seasons (Peluffo et al., 2006). Meanwhile McFatter (2007) mentioned that the density of Nearctic freshwater tardigrada species peaks up in the spring and / or fall. This disagreement indicates that more studies and more data are needed in this field.

\section{Taxonomy and phylogeny}

More than one thousand of Tardigrada species were included in the recently published checklist (Degma et al., 2009-2012). Based on morphological characteristics, the phylum of tardigrada is divided into two major classes: Heterotardigrada (armored tardigrades) and Eutardigrada (naked tardigrades) (Nichols et al., 2006).

The exact number of species of tardigrades is not known because of insufficient efforts invested in the tardigrades compared to other invertebrates (such as Insecta: Coleoptera), and that there is a need of engagement of more taxonomists and more extensive sampling areas (Guil, CabreroSañudo, 2007).

\section{Dormancy of tardigrades: anhydrobiosis}

Dormancy is an important adaptation strategy that allows many organisms to survive in unfavorable environmental conditions. Tardigrades have two forms of dormancy, namely cryptobiosis and encystment.

Tardigrades and some others organisms (Nematoda, Rotifera) are capable of entering a latent state (cryptobiosis) when environmental condi- tions are unfavorable, e. g. freezing, desiccation, low oxygen tension, and salinity variations. When tardigrada are in a latent state, their metabolism is reduced. In contrast to death, cryptobiosis is a reversible state and as soon as environmental conditions change, tardigrada return to life (Neuman, 2006). Five types of cryptobiosis are distinguished: encystment, anoxybiosis, cryobiosis, osmobiosis and anhydrobiosis (Nelson 2002; Bertolani et al., 2004; Watanabe, 2006).

To remain active, all tardigrades require water. One type of cryptobiosis, namely anhydrobiosis, is induced by water loss and occurs in eggs, juveniles and adults of terrestrial eutardigrades and echiniscids (Nelson, 2002; Rebecchi et al., 2007). Anhydrobiotic tardigrades always shrink in structure resembling "tun" when dehydrated (Wright, 2001; Bertolani et al., 2004; Watanabe, 2006). When tardigrades are desiccated at a low relative humidity or under anoxia they cannot form tun and be revived (Watanabe, 2006). Various species of tardigrada are characterized by interspecific differences in cryptobiotic (anhydrobiosis and cryobiosis) survival possibility (Jönsson et al., 2001; Bertolani et al., 2004).

Jönsson and Rebecchi (2002) indicate that the phenotypic state of the individuals has an impact on the probability to survive a period of anhydrobiosis. Effects of body size on anhydrobiotic survival suggest age - specific selection, and effects of energy status indicate that energy allocations to anhydrobiotic functions are also object to selection of evolution (Bertolani et al., 2004).

Biochemical mechanism of cryptobiosis (anhydrobiosis) is also an object of interest. Trehalose is known as a common compatible solute in anhydrobiotic organisms from unicellular organisms to invertebrates and higher plants. Trehalose may provide effective protection against desiccation because of its superior biochemical and physicochemical properties for stabilizing membranes and biomolecules including proteins and lipids (more about anhydrobiosis see review by Watanabe, 2006).

Trehalose is produced prior to the stages of anhydrobiosis and cryobiosis. Recently, it has become clear that the phenomenon of cryptobiosis is much more complex than initially thought to be. New results show that it is not only trehalose that is responsible for survival during cryobiosis 
and anhydrobiosis. Some species of tardigrades produce trehalose in small amounts (2-3\% of dry weight) compared to other invertebrates capable to devolve anhydrobiotic state (Jönsson, 2007). Hengherr et al. (2008) revealed significant differences between eight tardigrada species (Heterotardigrada and Eutardigrada) on the trehalose levels in different states of hydratation and dehydratation. Trehalose accumulation was found in some species of Eutardigrada but not detected in the species Milnesium tardigradum and no change in trehalose level had been observed in any species of Heterotardigrada (Hengherr et al., 2008). The study of Jönsson and Schill (2007) suggests that the desiccation cycles of some species of tardigrades are related with stress proteins of the family Hsp70. These proteins participate in unfolding and recolonization of proteins damaged by stresses and protect newly synthesized proteins from denaturation and aggregation (Watanabe, 2006). This group of proteins may play a role in the post-anhydrobiotic repair process (Jönsson, 2007). The phenomenon of cryptobiosis, when a tardigrada can go into a reversible death (ametabolic stage) for many years, and after a few minutes of rehydration can climb around again, might propose some hints to explain how life developed on earth.

\section{Significance of tardigrades}

Tardigrades share many characteristics with Caenorhabditis elegans and Drosophila that could make them useful as laboratory models, but there have been few studies of long-term culturing of tardigrades (Suzuki, 2003). Gabriel et al. (2007) demonstrated that the tardigrade Hypsibius $d u$ jardini can be cultured continuously for decades and can be cryopreserved. It has been reported that $H$. dujardini has a compact genome, a little smaller than that of C. elegans or Drosophila and can serve as a model for studying the evolution of developmental mechanisms (Gabriel et al., 2007).

Other significant feature of tardigrades is their tolerance to very high doses of ionizing radiation. Hydrated tardigrades have shown similar or higher tolerance to irradiation compared to dehydrated, anhydrobiotic tardigrades (Jönsson, 2007). This suggests that radiation tolerance in these animals is not restricted to biochemical protection mechanisms of the dry cells (Jönsson, 2007).
Tardigrades are relatively more vulnerable to UV irradiation than to $\gamma$-irradiation in the hydrated state (Jönsson, 2007). The observed tolerance to ionizing radiation, particularly in active tardigrades, may rely on an efficient DNA repair system. However, this mechanism of DNA repair will remain speculative and still must be verified (Jönsson, 2007).

Tardigrades with abilities to stand complete desiccation, cold and high levels of ionizing and UV radiation provide opportunity for studies on the response of living multicellular organisms exposed to open space (Jönsson, 2007).

Moreover, tardigrades may even be of economic interest due to their ability to undergo cryptobiosis, an environmentally resistant state, when conditions are unfavorable; the substances involved in cryptobiosis have potential applications in biomedicine and biotechnology (Guil, CabreroSañudo, 2007). The pharmaceutical industry has been very interested in the role of sugar trehalose that tardigrades produce prior to the stages of anhydrobiosis and cryobiosis. Trehalose appears to protect the cellular membranes of tardigrades against the damage of freezing and dehydration and therefore provide stability for biological products (Crowe et al., 1996). Vaccines and restriction enzymes can be stored in a trehalose formulated dry state at $+70{ }^{\circ} \mathrm{C}$ for one month without lost activity (Colaco et al., 1992). A number of biological products (monoclonal antibodies; pharmaceutical, foodstuff) have been stabilized using trehalose (Guo et al., 2000). Trehalose may be used in organ transplantation to avoid freezing damage and to safely preserve human eggs and those of endangered species, giving better options to young women facing cancer therapies that may leave them infertile and others who simply want to delay reproduction. Introduction of sugars into cells and into oocytes can protect them against freezing-associated stresses. Researchers injected the eggs of mouse with trehalose, cooled them to liquid nitrogen temperature, thawed them and exposed them to sperm. They got healthy babies at a similar rate to unfrozen controls (Eroglu et al., 2003).

These microscopic metazoans are significant as bioindicators of environmental pollution. Most terrestrial tardigrades live in mosses and lichens. Numerous studies proved that mosses are valuable bioaccumulators and the concentrations of the 
heavy metals in mosses closely correlate to atmospheric deposition (Vargha et al., 2002). Elevated heavy metal contents decrease the number of water bear species and of specimens, and abundance of tardigrada strongly depends on air pollution (Vargha et al., 2002). The moss-dwelling fauna could be a sufficiently sensitive tool for measuring the ecological consequences of pollution on the soil biota (Peluffo et al., 2006).

\section{Investigations of terrestrial tardigrades in the Baltic States}

The investigation of tardigrades in the Baltic States is insufficient. Two eutardigrade species groups: Paramacrobiotus richtersi and Macrobiotus hufelandi were recorded in Latvia (Ziemelis et al., 2012). Two species of genus Isohypsibius: Eremobiotus alicatai (Binda, 1969) and Isohypsibius marcellinoi (Binda, Pilato, 1971) were found in Estonia (Zawierucha, Kaźmierski, 2012). Little is known about tardigrades in Lithuania. Two genera: Macrobiotus sp. and Ramazzottius sp. have been reported in Lithuania two years ago (Šatkauskiené, Vosyliūte, 2010) and eight genera of tardigrades belonging to four families of eutardigrades have been found in Lithuania last year (Šatkauskienè, unpublished data, 12th International Symposium on Tardigrada, 2012).

\section{CONCLUSIONS}

Tardigrada are micrometazoans organisms with a cryptobiotic ability to survive in unfavourable environmental conditions. However, information of many aspects of their biology remain unclear. Irrespective of the most recent molecular investigations, phylogenetic position of these organisms still remains at the level of controversy. Data of the tardigrada relation with habitat type, substrate specificity and community ecology are not comprehensive. Little is known about their sexual dimorphism, sexual behaviour and gametogenesis. The tardigrades belonging to freshwater and marine species are especially scarcely described. Despite of the fact that they are common in moss, lichens and soil, the available information on tardigrada in Lithuania so far is very sparse.

Received 30 October 2012 Accepted 2 December 2012
References

1. Aguinaldo AM, Turbeville JM, Linford LS, Rivera MC, Garey JR, Raff RA, Lake JA. Evidence for a clade of nematodes, arthropods and other moulting animals. Nature 1997; 387: 489-93.

2. Altiero T, Rebecchi L, Bertolani R. Phenotypic Variations in the Life History of Two Clones of Macrobiotus richtersi (Eutardigrada, Macrobiotidae). Hydrobiologia 2006; 558: 33-40.

3. Avdonina AM, Biserova NM, Bertolani R, Rebecchi L. Ultrastructure of the digestive system of Ramazzottius tribulosus and Macrobiotus richtersi (Eutardigrada) in relationship with diet. J Limnol 2007; 66 (Suppl. 1): 5-11.

4. Baguley JG, Montagna PA. Physical-biological interactions controlling meiofauna standing stocks in the northern Gulf of Mexico deep sea. Twelfth International Meiofauna Conference, 2004; Ravenna, Italy.

5. Balsamo M, d'Hondt JL, Kisielewski J, Pierboni L. Global diversity of gastrotrichs (Gastrotricha) in fresh waters. Hydrobiologia 2008; 595: 85-91.

6. Bertolani R. Evolution of the reproductive mechanisms in tardigrades - a review. Zool Anz 2001; 240: 247-52.

7. Bertolani R, Rebecchi L, Claxton SK. Phylogenetic significance of egg shell variation in tardigrades. Zool J Linn Soc 1996; 116: 139-48.

8. Bertolani R, Guidetti K, Jonsson I, Altiero T, Boschini D, Rebecchi L. Experiences with dormancy in tardigrades. J Limnol 2004; 63: 16-25.

9. Colaco C, Sen S, Thangavelu M, Pinder S, Roser B. Extraordinary Stability of Enzymes Dried in Trehalose: Simplified Molecular Biology. Bio Technol 1992; 10: 1007-11.

10. Cromer L, Gibson JAE, McInnes SJ, Agius JT. Tardigrade remains from lake sediments. J Paleolimnol 2007; 39: 143-50.

11. Crowe LM, Reid DS, Crowe JH. Is Trehalose Special for Preserving Dry Biomaterials? Biophys J 1996; 71: 2087-93.

12. D’Addabbo R, Gallo M, De Leonardis C, Sandulli R, De Zio Grimaldi S. Further studies on the marine tardigrade fauna from Sardinia (Italy). Proceedings of the Tenth International Symposium on Tardigrada. J Limnol 2007; 66: 56-9.

13. Degma P, Bertolani R, Guidetti R. Actual checklist of Tardigrada species. 
14. Ver.21:2009-2012.http://www.tardigrada.modena.unimo. it/miscellanea/Actual $\% 20$ checklist $\%$ 20of\%20Tardigrada.pdf, pp. 36.

15. Dewel RA, Dewel WC. The place of tardigrades in arthropod evolution. In: Fortey RA, Thomas RH. (eds.) Arthropod relationships. 1997; Systematics Association Special Volume Series 55. Chapman \& Hall, London, p. 109-123.

16. Dewel RA, Dewel WC. The brain of Echiniscus viridissimus (Heterotardigrada): a key to understandung the phylogenetic position of tardigrades and the evolution of the arthropod head. Zool J Linn Soc 1996; 116: 35-49.

17. Dunn CW, Hejnol A, Matus DQ, Pang K, Browne WE, Smith SA, Seaver E, Rouse GW, Obst M, Edgecombe GD, Sųrensen MV, Haddock SHD, Schmidt-Rhaesa A, Okusu A, Mųbjerg Kristensen R, Wheeler WC, Martindale MQ, Giribet G. Broad phylogenomic sampling improves resolution of the animal tree of life. Nature 2008; 452: 745-9.

18. Eroglu A, Russo MJ, Bieganski R, Fowler A, Cheley S, Bayley H, Torner M. Intracellular trehalose improves the survival of cryopreserved mammalian cells. Nature Biotechnol 2000; 18: 163-7.

19. Eroglu A. Durable Critters Providing Insight For Human Egg Preservation. Medical College of Georgia (2006 December 21). Science Daily. http://www.sciencedaily.com

20. Eroglu A, Lawitts JA, Toner M, Toth TL. Quantitative microinjection of trehalose into mouse oocytes and zygotes, and its effect on development. Cryobiology 2003; 46: 121-34.

21. Gabriel WN, McNuff R, Patel SK, Gregory TR, Jeck WR, Jones CD, Goldstein B. The tardigrade Hypsibius dujardini, a new model for studying the evolution of development. Dev Biol 2007; 312: 545-59.

22. Gagyi-Palffy A, Stoian LC. A short review on tardigrades - some lesser known taxa of polyextremophilic invertebrates. ELBA Bioflux, 2011; 3(1): 13-26.

23. Garey JR, Schmidt-Rhaesa A. The essential role of 'minor' phyla in molecular studies of animal evolution. Amer Zool 1998; 38: 907-17.

24. Garey JR, McInnes SJ, Nichols PB. Global diversity of tardigrades (Tardigrada) in freshwater. Hydrobiologia 2008; 595: 101-6.

25. Giribet G, Carranza S, Bagui J, Riutort M, Ribera C. First Molecular Evidence for the Existence of a Tardigrada + Arthropoda Clade. Mol Biol Evol 1996; 13: 76-84.

26. Greven H, Kristensen RM. Some Aspects of Spermiogenesis and Spermatozoan Ultrastructure in Echiniscoides sigismundi (Heterotardigrada: Echiniscoididae). J Comp Zool 2001; 240 : 331-9.

27. Greven H. Comments on the eyes of tardigrades. Arthr Struc Dev 2007; 36: 401-7.

28. Guidetti R, Altiero T, Marchioro T, Amade LS, Avdonina AM, Bertolani R, Rebecchi L. Form and function of the feeding apparatus in Eutardigrada (Tardigrada). Zoomorphology 2012; 131: 127-48.

29. Guidetti R, Colavita Ch, Altiero T, Bertolani R, Rebecchi L. Energy allocation in two species of Eutardigrada. J Limnol 2007; 66: 111-8.

30. Guidetti R, Boschini D, Rebecchi L, Bertolani R. Encystment processes and the "Matrioshka-like stage" in a moss-dwelling and in a limnic species of eutardigrades (Tardigrada). Hydrobiologia 2006; 558: 9-21.

31. Guidetti R, Bertolani R, Nelson DR. Ecological and faunistic studies on tardigrades in leaf litter of beech forests. In: H. Greven (ed.). Proceedings of the seventh international symposium on the Tardigrada, August 1997, Düsseldorf, Germany. Zool Anz 1999; 238: 215-23.

31a. Guil N, Cabrero-Sañudo FJ. Analysis of the species description process for a little known invertebrate group: the limnoterrestrial tardigrades (Bilateria, Tardigrada). Biodiv Conserv 2007; 16: 1063-86.

32. Guo N, Puhlev I, Brown DR, Mansbridge J, Levine $\mathrm{F}$. Trehalose expression confers desiccation tolerance on human cells. Nature Biotechnol 2000; 18: 168-71.

33. Hansen JG, Katholm AK. A study of the genus Amphibolus from Disko Island with special attention on the life cycle of Amphibolus nebulosus (Eutardigrada: Eohypsibiidae). In: Hansen JG. (ed.). Arctic Biology Field Course Quqertarsuaq 2002. Zoological Museum University of Copenhagen H. C. Ų. TRYK Copenhagen: 129-63.

34. Hansen GH, Kristensen RM. The 'hyena female' of tardigrades and descriptions of two new species of Megastygarctides (Arthrotardigrada: Stygarctidae) from Saudi Arabia. Hydrobiologia 2006; 558: 81-101.

35. Hengherr S, Heyer AG, Kãhler R, Schill RO. Trehalose and anhydrobiosis in tardigrades - evi- 
dence for divergence in responses to dehydration. FEBS J 2008; 275(2): 281-8.

36. Hanelt B, Thomas F, Schmidt-Rhaesa A. Biology of the phylum Nematomorpha. Adv Parasitol 2005; 59: 243-305.

37. Harada H, Ito MT. Soil-inhabiting tardigrade communities in forests of Central Japan. Hydrobiologia 2006; 558: 119-27.

38. Hohberg K. Tardigrade species composition in young soils and some aspects on life history of Macrobiotus richtersi J. Murray, 1911. Pedobiologia 2006; 3: 267-74.

39. Horikawa DD, Sakashita T, Katagiri C, Watanabe M, Kikawada T, Nakahara Y, Hamada N, Wada S, Funayama T, Higashi S, Kobayashi Y, Okuda T, Kuwabara M. Radiation tolerance in the tardigrade Milnesium tardigradum. Int J Radiat Biol 2006; 82: 843-8.

40. International symposium on Tardigrada. Abstract Booklet. V. N. Gaia. Portugal, 2012: 1-103.

41. Jeschke JM, Hohberg K. Predicting and testing functional responses: An example from a tardigrade-nematode system. Bass Appl Ecol 2008; 9: $145-51$.

42. Jönsson IK. Population density and species composition of moss-living tardigrades in a boreonemoral forest. Ecography 2003; 26: 356-64.

43. Jönsson I, Rebecchi L. Experimentally induced anhydrobiosis in the tardigrade Richtersius coronifer: phenotypic factors affecting survival. J Exp Zool 2002; 293: 578-84.

44. Jönsson KI, Bertolani R. Facts and fiction about long-term survival in tardigrades. J Zool 2001; 255: 121-3.

45. Jönsson KI, Harms-Ringdahl M, Jesper T. Radiation tolerance in the eutardigrade Richtersius coronifer. Int J Radiat Biol 2005; 81: 649-56.

46. Jönsson KI. Tardigrades as a Potential Model Organism in Space Research. Astrobiology 2007; 7: 757-66.

47. Jönsson KI, Shill RO. Induction of Hsp70 by desiccation, ionising radiation and heat-shock in the eutardigrade Richtersius coronifer. Comparative Biochemistry and Physiology - Part B: Biochemistry \& Molecular Biology 2007; 146: 456-60.

48. Jǿrgensen A, Kristensen RM. Molecular phylogeny of tardigrada - investigation of the monophyly of Heterotardigrada. Mol Phylogenet Evol 2004; 32(2): 666-70.
49. Kinchin IM. On the significance of a "minor" phylum (The Tardigrada) in the context of a constructivist view of knowledge. Perspect Biol Med 2000; 2: 243-51.

50. Kinchin IM. What is a tardigrade? J Microsc (London) 1992; 36: 628-34.

51. Klekowski RZ, Opalinski KW. Oxygen consumption in Tardigrada from Spitsbergen. Polar Biol 1989; 9: 299-303.

52. Köhler H-R, Kloas W, Schirling M, Lutz I, Reye AL, Langen JS, Triebskorn R, Nagel R, Schönfelder G. Sex steroid receptor evolution and signalling in aquatic invertebrates. Ecotoxicology 2007; 16: 131-43.

53. Kieneke A, Martinez A, Fontaneto P. Spatially structured populations with a low level of cryptic diversity in European marine Gastrotricha. Mol Ecol 2012; 21: 1239-54.

54. Krantz S, Benoit TG, Beasley CW. Phytopathogenic bacteria associated with Tardigrada. Zool Anz 1999; 238: 259-60.

55. Kristensen RM. An Introduction to Loricifera, Cycliophora, and Micrognathozoa. Integr Comp Biol 2002; 42: 641-51.

56. Massard JA, Geimer GE. Global diversity of bryozoans (Bryozoa or Ectoprocta) in freshwater. Hydrobiologia 2008; 595: 93-9.

57. McFatter MM, Meyer HA, Hinton JG. Nearctic freshwater tardigrades: a review. J Limnol 2007; $66: 84-9$.

58. McInnes S, Pugh P. Biogeography of limno-terrestrial Tardigrada, with particular reference to the Antarctic fauna. J Biogeogr 1998; 25: 31-6.

59. Meyer HA. The Terrestrial and Freshwater Tardigrada of Northeastern America, with New Records from Maine. Northeastern Naturalist 2011; 18: 534-41.

60. Meyer HA, Hinton JG. Limno-terrestrial Tardigrada of the Nearctic Realm. J Limnol 2007; 66: 97-103.

61. Meyer HA. Interspecific association and substrate specificity in tardigrades from Florida, Southeastern United States. Hydrobiologia 2006; 558: 129-32.

62. Mildažienè V, Naučienė Z. Vandens lašas miegančiai stiklo karste gražuolei pažadinti 2007; http://gamta.vdu.lt/bakalaurai/mok_straipsniai. htm.

63. Miller WR, Heatwole HF. Tardigrades of the Australian Antarctic Territories: the Northern Prince 
Charles Mountains, East Antarctica. Proc Linn Soc NSW 1996; 116: 245-60.

64. Miller WR, Claxton SK, Heatwole HF. Tardigrades of the Australian Antarctic Territories: Males in the genus Echiniscus (Tardigrada: Hetrotardigrada). J Comp Zool 1999; 238: 303-9.

65. Mitchell CR, Romano FA. Sexual dimorphism, population dynamics and some aspects of life history of Echiniscus mauccii (Tardigrada; Heterotardigrada). J Limnol 2007; 66: 126-31.

66. Müller KJ, Walossek D, Zakharov A. 'Orsten' type phosphatized soft-integument preservation and a new record from the Middle Cambrian Kuonamka Formation in Siberia. N Jb Geol Paläont Abh 1995; 191: 101-18.

67. Nelson D, Guidetti R, Rebecchi L. Tardigrada. In: Thorp JH, Covich AP (eds.). Ecology and classification of North American Freshwater Invertebrates, 3rd edn. Academic Press (Elsevier), San Diego 2010; 14: 455-84.

68. Nelson DR. Current status of the Tardigrada: Evolution and Ecology. Integr Comp Biol 2002; 42: 652-9.

69. Neuman Y. Cryptobiosis - A new theoretical perspective. Prog Biophys Mol Bio 2006; 92: 258-67.

70. Nichols PB, Nelson DR, Garey JR. A Family Level Analysis of Tardigrade Phylogeny. Hydrobiologia, 2006; 558: 53-60.

71. Nielsen C. Animal Evolution: Interrelationships of the Living Phyla. Oxford University Press, Oxford; 2001.

72. Paps J, Riutort M. Molecular phylogeny of the phylum Gastrotricha: New data brings together molecules and morphology. Mol Phyl Evol 2012; 63: 208-12.

73. Peluffo MC, Peluffo RJ, Rocha MA, Doma LI. Tardigrade distribution in medium-sized city of central Argentina. Hydrobiologia 2006; 558: 141-50.

74. Peterson KJ, Eernisse DJ. Animal phylogeny and the ancestry of bilaterians: inferences from morphology and $18 \mathrm{~S}$ rDNA gene sequences. Evol Dev 2001; 3: 170-205.

75. Pilato G, Binda MG, Biondi O, D'Urso V, Lisi O, Marletta A, Maugeri S, Nobile V, Rappazzo G, Sabella G, Sammartano F, Turrisi G, Viglianisi F. The clade Ecdysozoa, perplexities and question. Zool Anz 2005; 244: 43-50.
76. Pilato G, Guidetti R, Rebecchi L, Lisi O, Hansen GJ, Bertolani R. Geonemy, ecology, reproductive biology and morphology of the tardigrade Hypsibius zetlandicus (Eutardigrada: Hypsibiidae) with erection of Borealibius gen. n. Polar Biol 2006; 29: 595-603.

77. Pilato G, Binda MG. Definition of families, subfamilies, genera and subgenera of the Eutardigrada, and keys to their identification. Zootaxa 2010; 2404: 1-52.

78. Poinar G. Global diversity of hairworms (Nematomorpha: Gordiaceae) in freshwater. Hydrobiologia 2008; 595: 79-83.

79. Poprawa I. The structure and the formation of egg shells in the parthenogenetic species Dactylobiotus dispar Murray, 1907 (Tardigrada: Eutardigrada). Tissue Cell 2005; 37: 385-92.

80. Rebecchi L, Altiero T, Guidetti R. Anhydrobiosis: the extreme limit of desiccation tolerance. Invertebr Surviv J 2007; 4: 65-81.

81. Rebecchi L, Guidi A, Bertolani R. Mutarotative pattern of the ovotestis in two hermaphrodite species of eutardigrada. Invertebr Reprod Dev 2000; 37: 25-34.

82. Regier JC, Shultz JW, Kambic RE. Pancrustacean phylogeny: hexapods are terrestrial crustaceans and maxillopods are not monophyletic. P Roy Soc Lond Bio Series B. Biological Sciences 2005; 272: 395-401.

83. Rocha AM, Izaguirre MF, Peluffo MC, Peluffo JR, Casco VH. Ultrastructura of the cuticle of Echiniscus rufoviridis (Du Bois-Raymond Marcus, (1944) Heterotardigrada) Acta Microscop 2007; 16: 16-21.

84. Romano FA. Symposium: Insect Behavioral Ecology - 2001. On water bears. Florida Entomologist 2003; 86(2): 131-7.

85. Romano FA, Barreras-Borrero B, Nelson DR. Ecological Distribution and Community Analysis of Tardigrada from Choccolocco Creek, Alabama. J Comp Zool 2001; 240: 535-41.

86. Roser BJ. Trehalose drying: a novel replacement for freeze-drying. Biopharmacology 1991; 5: 44-53.

87. Roser B. Single-shot stable liquid vaccines. Innov Pharmac Technol 1991; 50-4.

88. Ryu HS, Lee JM, Jang KH, Choi EH, Park SJ, Chang ChY, Kim W, Hwang UW. Partial Mitochondrial Gene Arrangements Support a Close 
Relationship between Tardigrada and Arthropoda. Mol Cells 2007; 24: 351-7.

89. Ryland J. Bryozoa: an introductory overview. Denisia 2005; 16: 9-20.

90. Schmidt-Rhaesa A, Kulessa J. Muscular architecture of Milnesium tardigradum and Hypsibius sp. (Eutardigrada, Tardigrada) with some data on Ramazottius oberhaeuseri. Zoomorphology 2007; 126: 265-81.

91. Schmidt-Rhaesa A. Tardigrades - Are They Really Miniaturized Dwarfs? Zool Anz 2001; 240: 549-55.

92. Steiner WA. The influence of air pollution on moss dwelling animals: 2. Aquatic fauna with emphasis on Nematoda and Tardigrada. Rev Zool 1994b; 101: 699-724.

93. Steiner WA. The influence of air pollution on moss dwelling animals: 4 . Seasonal and long-term fluctuations of rotifer, nematode and tardigrade populations. Rev Zool 1994c; 101: 1017-31.

94. Strayer DL. Challenges for freshwater invertebrate conservation. JN Am Benthol Soc 2006; 25: 271-87.

95. Suzuki AC. Life history of Milnesium tardigradum Doyere (Tardigrada) under a rearing environment. Zool Sci 2003; 20: 49-57.

96. Šatkauskienė I, Vosyliūtė R. Microfauna of moss from four regions of Lithuania. Acta Zool Lith 2012; 20: 225-31.

97. Vargha B, Ötvös E, Tuba Z. Investigations on ecological effects of heavy metal pollution in Hungary by moss-dwelling water bears (Tardigrada), as bioindicators. Ann Agric Environ Med 2002; 9: 141-6.

98. Villora-Moreno S. 1998. Deep-sea Tardigrada from South Shetland Islands (Antarctica) with description of Angursa antarctica sp. nov. (Arthrotardigrada, Halechiniscidae). Polar Biol 2002; 19: 336-41.

99. Watanabe M. Anhydrobiosis in invertebrates. Appl Entomol Zool 2006; 41: 15-31.

100. Wright JC. Cryptobiosis 300 years on from van Leuwenhoek: what have we learned about tardigrades? Zool Anz 2001; 240: 563-82.

101. Zantke J, Wolff C, Scholtz G. Three-dimensional reconstruction of the central nervous system of Macrobiotus hufelandi (Eutardigrada, Parachela): implications for the phylogenetic position of Tardigrada. Zoomorphology 2008; 127: $21-36$.
102. Zawierucha K, Kaźmierski A. The first records of tardigrades (Tardigrada, Eutardigrada) from Estonia. Zool Ecol 2012; 22: 111-3.

103. Ziemelis A, Purina L, Ozolinš A. A Short-term study of population dynamics of tardigrades in the moss Leucodon sciuroides (Hedw.). SCHWÄGR Latvijas Universitātes 70 zinātniskā konference Bioloăijas sekcija, Zooloăijas un dzīvnieku ekoloăijas apakšsekcija; 2012.

\section{Ingrida Šatkauskienè}

\section{BALTIJOS ŠALIŲ LE்TŪNAI}

\section{Santrauka}

Straipsnyje apžvelgiama viena mikroskopinių daugialąsčių organizmų grupè - lètūnai (Tardigrada), išplitę ivairioje aplinkoje: samanose, kerpése, dirvožemyje, gèlame ir jūriniame vandenyje. Dėl kriptobiotinių biologinių savybių ir jų pritaikymo lètūnai pastaruoju metu sulaukia nemažai pasaulio mokslininkų dėmesio. Straipsnyje pateikiami kelerių pastarųjų metų duomenys apie lètūnų paplitimą, taksonomiją ir filogeniją, aptariami kai kurie biologijos, dauginimosi ir ekologijos ypatumai. Pateikiama informacija apie lètūnų ištyrimą Baltijos šalyse.

Raktažodžiai: lètūnai, anhidrobiozè, kriptobiozè, gèlavandeniai, eutardigrada, heterotardigrada 
